\title{
Importance of amylases for physiological quality in maize seeds
}

\author{
Camila Aparecida Lopes * \\ Maria Laene Moreira de Carvalho \\ Heloisa Oliveira dos Santos \\ Dayliane Bernardes de Andrade
}

\author{
Programa de Pós-Graduação em Agronomia/Fitotecnia \\ Departamento de Agricultura, Setor de Sementes, Universidade Federal de Lavras \\ Caixa Postal 3037, CEP 37200-000, Lavras - MG, Brasil \\ * Autor para correspondência \\ camilalopes_sjc@hotmail.com
}

Submetido em 16/11/2016

Aceito para publicação em 20/06/2017

\section{Resumo}

Importância das amilases na qualidade fisiológica de sementes de milho. A qualidade de sementes está associada à soma dos atributos genéticos, físicos, fisiológicos e sanitários que afetam sua capacidade para realizar as funções vitais, estando relacionada à germinação, ao vigor e à longevidade. A expressão de genes associados à qualidade fisiológica pode ser avaliada por meio de análises de germinação e vigor, e ainda pelas análises de transcritos e de proteínas em sementes. Objetivou-se com este trabalho fazer uma revisão sobre a relevância das enzimas do grupo das amilases relacionadas à qualidade fisiológica de sementes de milho. Dentro do grupo das amilases, a $\alpha$-amilase (1,4- $\alpha$-D-glucan-glucanohydrolase, E.C 3.2.1.1) é uma enzima importante na hidrólise do amido, sendo responsável por $90 \%$ da atividade amilolítica em sementes de milho. Essa enzima, a exemplo da dextrose, causa a conversão de amido em açúcares que são utilizados no crescimento do embrião. Já a $\beta$-amilase (1,4- $\alpha$-D-glucan maltohydrolase, E.C 3.2.1.2) catalisa a liberação de maltose e dextrinas a partir das extremidades não redutoras do amido. Pesquisas comprovam que as enzimas amilases estão ligadas diretamente à qualidade fisiológica de sementes de milho. A $\alpha$-amilase e a $\beta$-amilase estão envolvidas principalmente no processo de germinação e na heterose das sementes, podendo ser também utilizadas como marcadores moleculares relacionadas à tolerância de secagem das sementes.

Palavras-chave: $\alpha$-amilase; $\beta$-amilase; Germinação; Heterose; Marcador molecular

\section{Abstract}

Seed quality is the result of the sum of genetic, physical, physiological and sanitary attributes that affect seed ability to perform vital functions related to germination, vigor, and longevity. The expression of genes associated with physiological quality can be assessed by means of germination and vigor analyses, as well as by transcript and protein analyses. The objective in this work was to review the relevance of amylase group enzymes to the physiological quality of maize seeds. Within this group, $\alpha$-amylase $(1,4-\alpha-\mathrm{D}$-glucan glucanohydrolase E.C 3.2.1.1) plays an important role in starch hydrolysis, and is responsible for $90 \%$ of the amylolytic activity in 
maize seeds. It is responsible for starch conversion into sugars (e.g., destrin), which is used for embryo growth. $\beta$-amylase (1,4- $\alpha$-D-glucan maltohydrolase E.C 3.2.1.2) catalyzes the release of maltose and dextrins from the non-reducing ends of starch. Research has shown that amylase enzymes are directly linked to physiological quality of maize seeds. Alpha- and beta-amylases are mainly involved in the germination process and seed heterosis, and can also be used as molecular markers associated with seed tolerance for drying.

Key words: $\alpha$-amylase; $\beta$-amylase; Germination; Heterosis; Molecular marker

\section{Introduction}

Maize (Zea mays) is a crop of great economic importance, and an important component of both domestic and international agricultural markets. In order to meet grain market demands in 2013/2014, the global harvested area was 15.8 million hectares, producing approximately 425,000 tons of seeds with $90 \%$ seeds utilization rate (ABRASEM, 2014). There has been significant growth in maize seed production over the last decades, with 2000/2001 harvest values significantly lower at 172,000 tons (ANDRADE, 2015). Maize currently represents a significant portion of the national seed market, corresponding to roughly $45 \%$ (ABRASEM, 2014).

Seed physiological quality is influenced by genotype, environment, and interactions among them (JOSÉ et al., 2004a; MEYER et al., 2012; ANDRADE, 2015), and genotype assessment is important component of the seed selection process in breeding programs. However, maize breeding programs lack general criteria for evaluating seed quality during the selection process, and instead rely on assays for registration of physiological features for new cultivars. After development some cultivars, even productive ones, show low physiological quality, which reduces input to the crop market.

Seeds quality is the result of the sum of the genetic, physiological, physical, and sanitary attributes which affect germination, vigor, and longevity. Physiological quality can be evaluated by means of germination and vigor analyses, as well as by analysis of gene transcripts and proteins known to be associated with quality. According to Leymarie et al. (2011), the major group of genes that are directly associated with maize seed quality are those encoding amylases. However, other genes such as those related to desiccation tolerance, respiration, and scavenger enzymes may also be associated with physiological quality (ANDRADE, 2015).

During the germination process, the embryo produces and secretes natural gibberellin into the endosperm. These hormones induce the development of hydrolytic enzymes such as $\alpha$-amylase (EC 3.2.1.1.) and $\beta$-amylase (EC 3.2.1.2.) in the aleurone layer, which causes degradation of the locally synthesized endosperm reserves (OLIVEIRA et al., 2013).

The enzyme $\alpha$-amylase plays an important role in starch hydrolysis, and is responsible for $90 \%$ of amylolytic activity in maize seeds. It constitutes a family of endoamylases that catalyze the hydrolysis of glycosidic linkages between $\alpha-1.4$ starch, glycogen, and other carbohydrates (FRANCO et al., 2002). $\beta$-amylase is an $\alpha$-1.4-D-glucan maltohydrolase (EC 3.2.1.2.) is synthesized during the seed development process (OLIVEIRA, 2013), and catalyzes the release of maltose and dextrins from the non-reducing ends of starch These two enzymes are known to be related to seed quality, thus studies of gene expression in these enzymes my help us to better understand their genetic behavior, and may assist in breeding programs focused on seed physiological quality.

The objective in this study was to review gene expression in amylase enzymes linked to physiological quality of maize seeds.

\section{Development}

High quality seed is essential for success in establishing crops and obtaining high yields in maize (ABRASEM, 2014). Some research has shown that the physiological quality of maize seed (Zea mays) is influenced not only by environmental factors, but also by the genotype and its interactions with the environment 
(HOECKER et al., 2006; REIS et al., 2011; OLIVEIRA et al., 2013; ANDRADE, 2015). Many authors such as Rood et al. (1990), Causse et al. (1995), Gomes et al. (2000), José et al. (2004b), Hoecker et al. (2006) and Reis et al. (2011) relate quality to the influence of heterosis or hybrid vigor in seed germination. In several of these studies, hybrid plants were found to have more efficient enzyme systems compared to other lineages. Oliveira et al. (2015) observed higher expression of amylase enzymes in hybrid seed, indicating heterosis with respect to expression of these enzymes. These enzymes play a crucial role in many metabolic reactions, including synthesis and biodegradation of molecules during development and seed deterioration (PIMENTEL et al., 2012). This explains the higher vigor of hybrid seeds (OLIVEIRA et al., 2013).

Paleg (1965), in biochemical studies manipulating $\alpha$-amylase synthesis and subsequent hydrolysis of the seed reserves, found a direct relationship between gibberellin synthesis and maize heterosis. According to Rood et al. (1990) and Oliveira et al. (2013), maize lineages are less vigorous than their descendant hybrids, in part because of gibberellin deficiency. These authors also found a positive correlation between seedling gibberellin content and growth rate, leaf area, and height of maize plants. The authors also report that one of the causes of endogamy depression is gibberellin deficiency. Mino and Inoue (1994) found that high germination speed and vigorous seedling growth are associated with higher metabolic expression of RNA, DNA, and proteins in embryos. The authors also found that protein and lipid metabolism in hybrid seed embryos is superior to that of single lineages, promoting greater embryonic axis growth and higher seed germination. Causse et al. (1995) observed a positive relationship between sucrose phosphate synthase (SPS) activity and initial vegetative growth in maize seedlings. The highest SPS activity, which occurred in seedlings from hybrid seeds, was also correlated with higher dry matter production (OLIVEIRA et al., 2013). Rood and Larsen (1998) investigated the involvement of $\alpha$-amylase in heterosis in maize seedlings and found that after $48 \mathrm{~h}$ of seed imbibition, enzyme activity and gibberellic acid content $\left(\mathrm{GA}_{3}\right)$ in hybrid seed was higher than in parental lines, resulting in more rapid hydrolysis of maize starch.
Among the numerous studies on maize enzyme activity, we highlight Rood and Larsen (1988), who demonstrated a relationship between gibberellins (GAs) and amylases and heterosis. The authors evaluated two lineages and their respective hybrids, and found that the largest endogenous GA concentration in hybrid seed was associated with increased $\alpha$-amylase activity in the hybrid seedlings, and thus, faster hydrolysis of starch, which serves as fuel for initial growth in seedlings. These results are consistent with the hypothesis that GAs control $\alpha$-amylase biosynthesis, which is involved in the regulation of heterosis in maize seeds (OLIVEIRA, 2013).

Seed companies, as an internal control, evaluate the physiological quality of seeds by germination tests, cold tests, and artificial aging tests (CATÃO et al., 2010; COIMBRA et al., 2009). In addition to the physiological tests, some studies have associated the expression of enzymes (tested through electrophoresis) with the physiological quality of seeds (JOSÉ et al., 2004b; OLIVEIRA et al., 2013). According to Copeland and McDonald (2001), more sensitive assessments for detecting early seed deterioration can be made through evaluation of enzyme activity associated with biosynthesis of new tissue, as these enzymes become less efficient in terms of catalytic activity along the process of deterioration. It is in this context that $\alpha$ and $\beta$-amylase expression can be associated with the physiological quality of maize seed. However, Oliveira et al. (2013) found differential expression of amylase enzymes in seeds from lineages with different levels of physiological quality, and noted that the highest expression of these enzymes does not necessarily occur in higher quality seed lineages. Andrade et al. (2013) also found that in addition to the amylase enzymes, the LEA (late embryogenesis abundant) and SOD (superoxide dismutase) proteins are also related to physiological quality in maize seeds. The LEA proteins act in membrane stabilization and cytoplasm protection during dehydration, promoting desiccation and seed storage tolerance (Hong-Bo et al., 2005). The SOD proteins act in catalysis of superoxides $\left(\mathrm{O}_{2}^{-}\right)$and conversion to hydrogen peroxide $\left(\mathrm{H}_{2} \mathrm{O}_{2}\right)$ (KIBINZA et al., 2011). 
The $\alpha$ - and $\beta$-amylases are involved in the main system of starch degradation (Vieira et al., 2008). According to Santos et al. (2010), identifying peaks in amylase activity during germination is essential, since the amylase activity can be detected during the beginning of seed germination, and its primary role is providing substrate for use in seedlings until they become efficient photosynthetically. Aragão et al. (2003) found the highest germination rates and vigor in maize seeds with the greatest $\alpha$-amylase activity. Ferreira et al. (2007) also found the highest biostimulant efficiency in maize seeds with the highest $\alpha$-amylase activity. A survey conducted by Muniz et al. (2007) showed that even allelopathic effects of weeds in crops such as maize, beans, soy, and lettuce can be analyzed using $\alpha$-amylase and $\beta$-amylase activity assays, since these enzymes suffer direct interference by allelochemicals, resulting in lower efficiency and consequently, lower seed germination rates and less vigor.

RT-PCR is an efficient method for identifying $\alpha$-amylase expression during seed germination (DANTAS et al., 2002). Oliveira et al. (2013) used qRT-PCR to study the amylase expression in seeds from maize lineages with different levels of physiological quality, and concluded that this technique can be used to assist in genotype selection in breeding programs by facilitating elimination of genotypes with lower quality seeds in early stages of selection.

Vieira et al. (2008) found that many seed dormancy types arise from the blockade of $\alpha$-amylase action. Timóteo and Marcos-Filho (2013) propose that seed storage potential should be evaluated by germination and vigor assays, as well as through assessment of isoenzyme activity, including $\alpha$-amylase. Wattanakulpakin et al. (2012) showed that artificially aged seeds have reduced $\alpha$-amylase activity. This result differs from that of Ramos and Carneiro (1991), which observed an increase of amylase enzyme activity with increased aging time.

In Zea mays, $\alpha$ - and $\beta$-amylases are important because maize seed is rich in starch, the main reserve substance, which represents $70 \%$ of the total grain weight (WU et al., 2009). Common maize starch is a mixture of approximately $28 \%$ amylose and $72 \%$ amylopectin. During seed germination, the insoluble reserves with high molecular weight are degraded and converted to soluble forms, which are quickly transported to tissue for growth and use in synthesis reactions or energy production (OLIVEIRA et al., 2013). According Bewley et al. (2013) metabolic modifications during germination result from activity of many enzymes, including the $\alpha$ and $\beta$-amylases.

$\beta$-amylase is an $\alpha$-1.4-D-glucan malto hydrolysis (EC 3.2.1.2.) that catalyzes the release of maltose and dextrins from the non-reducing ends of starch. $\beta$-amylase is synthesized during seed development process (MASON-GAMER, 2005). In dried seeds $\beta$-amylase is found in two forms: a free, active form; and a less active form which represents approximately $75 \%$ of total $\beta$-amylase. $\beta$-amylase actively released during germination is accompanied by additional accumulation of its isoforms (SOPANEN; LAURIÈRE, 1989; OLIVEIRA et al., 2013).

The enzyme $\alpha$-amylase is important in starch hydrolysis, accounting for $90 \%$ of amylolytic activity in maize seeds (LI et al., 2007). It drives starch conversion into sugars used for embryo growth (HENNING et al., 2010). The $\alpha$-amylases constitute an endoamylase family which catalyze the hydrolyzing the $\alpha-1.4$ glycosidic linkages in starch, glycogen and other carbohydrates (FRANCO et al., 2002). It is usually not present in dry seed, and is synthesized and secreted in the aleurone layer during germination (KIGEL; GALILI, 1995). Synthesis of this enzyme occurs in response to signals produced by the embryo (ARAGÃO et al., 2001). Studies on the development and hormonal regulation of gene expression revealed that induction of $\alpha$-amylase results in de novo synthesis, accompanied by a pronounced increase in mRNA for protein manufacture. In cereals, this induction responds positively to gibberellins (GA) and negatively to abscisic acid. Gibberellin is secreted by the embryo in the aleurone layer and scutellum, inducing $\alpha$-amylase mRNA synthesis which increases in parallel with enzyme synthesis activity in the cotyledon (BECK; ZIEGLER, 1989). According to Oliveira et al. (2013), the highest amylase enzyme expression is observed in imbibed maize seeds. Vieira et al. (2002) also noted that there was an increase in $\alpha$-amylase activity after imbibition. However, Fries et al. (2007) showed that in 
conditions of water excess, $\alpha$-amylase enzyme activity is greatly reduced.

The synthesis and segregation of $\alpha$-amylase begins in the scutellum rapidly and for a brief period, no later than the fourth day, since the aleurone layer needs more time to accomplish the synthesis and segregation of $\alpha$-amylase. However, the aleurone layer can secrete higher quantities of $\alpha$-amylase and for a longer period of time. It is estimated that the peak in $\alpha$-amylase synthesis occurs between five and seven days, gradually decreasing until the end of germination (SUBBARAO et al., 1998).

Gibberellins are involved in regulating mobilization of reserves, however, germination and seedling growth may occur after seed imbibition, thus seed drying is required to sensitize the aleurone layer to gibberellic acid and activate $\alpha$-amylase synthesis (ROSA et al., 2000; OLIVEIRA et al., 2013). During seed germination, the gibberellins are synthesized in the embryo and secreted in the aleurone layer (LOVEGROVE; HOOLEY, 2000; CHEN et al., 2013). In the aleurone cells, the gibberellins are detected by receptors such as GID1, degrading negative regulators (e.g., DELLA proteins) and iincreasi cytoplasmic $\mathrm{Ca}^{2+}$ and cGMP, which then causes induction of trans-activators induction and $\alpha$-amylase expression (NAKAJIMA et al., 2006; XIE et al., 2007).

According to Oliveira et al. (2013) and Carvalho and Nakagawa (2012), many studies have been developed to detect the various metabolic reactions involving the synthesis and degradation of molecules during maize development, germination, and seed deterioration. These authors claim that during the seed maturation phase, analysis of reserve material accumulation through molecular markers may allow assessment of seed quality, and that $\alpha$-amylase activity has been used as marker for desiccation tolerance in maize seeds. This result is in agreement with that of José et al. (2004b), in which isoenzymatic profiles for $\alpha$-amylase showed a higher bandwidth for lineage and hybrid seeds that are tolerant to high drying temperature. Further, Andrade et al. (2013) also found expression of these enzymes in in relation to heat resistance in maize seeds. Biazus et al. (2006) in their work concluded that amylases work at optimum temperature range from 25 ${ }^{\circ} \mathrm{C}$ to $30^{\circ} \mathrm{C}$.

In general, our review indicates that amylase enzymes are connected directly to physiological quality of maize seeds. The enzymes $\alpha$-amylase and $\beta$-amylase are mainly involved in the germination process and seed heterosis, and may also be used as molecular markers for traits related to seed quality.

\section{Acknowledgements}

The Coordination for Improvement of Higher Education Personnel (Capes) and the National Council for Scientific and Technological Development (CNPq) granted scholarships and financial support for development of the research.

\section{References}

ABRASEM - ASSOCIAÇÃO BRASILEIRA DE SEMENTES E MUDAS. Anuário 2014. Londrina, 2014. 34 p. Disponível em: $\quad<$ http://www.abrasem.com.br/wpcontent/uploads/2013/09/ Anu\%C3\%A1rio-Abrasem-2014.pdf>. Acesso em: 18 nov. 2016.

ANDRADE, T. de. Controle genético e expressão de genes associados à qualidade fisiológica de sementes de milho. 2015. 122 f. Tese (Doutorado em Agronomia/Fitotecnia) - Universidade Federal de Lavras, Lavras. 2015.

ANDRADE, T.; VON PINHO, E. V., VON PINHO, R. G.; OLIVEIRA, G. E.; ANDRADE, V.; FERNANDES, J. S. Physiological quality and gene expression related to heat-resistant proteins at different stages of development of maize seeds. Genetics and Molecular Research, Ribeirão Preto, v. 12, n. 3, p. 3630-3642, 2013.

ARAGÃO, C. A.; DANTAS, B. F.; ALVES, E.; CATANEO, A. C.; CAVARIANI, C; NAKAGAWA, J. Atividade amilolítica e qualidade fisiológica de sementes armazenadas de milho super doce tratadas com ácido giberélico. Revista Brasileira de Sementes, Londrina, v. 25, n. 1, p. 43-48, 2003.

ARAGÃO, C. A.; LIMA, M. W. P.; MORAIS, O. M.; ONO, E. O.; BOARO, C. S. F.; RODRIGUES, J. D.; NAKAGAWA, J.; CAVARIANI, C. Fitorreguladores na germinação de sementes e no vigor de plântulas de milho super doce. Revista Brasileira de Sementes, Londrina, v. 23, n. 1, p. 62-67, 2001.

BECK, E.; ZIEGLER, P. Biosynthesis and degradation of starch in higher plants. Annual Review of Plant Physiology and Plant Molecular Biology, Palo Alto, v. 40, n. 1, p. 95-117, 1989.

BEWLEY, J. D.; BRADFORD, K.; HILHORST, H.; NONOGAKI, H. Seeds: physiology of development, germination and dormancy. New York: Springer, 2013. 392 p.

BIAZUS, J. P. M.; SANTANA, J. C. C.; SOUZA, R. R.; TAMBOURGI, E. B. Caracterização da atividade amilásica do 
malte de milho (Zea mays L.). Acta Scientiarum. Technology, Maringá, v. 28, n. 1, p. 13-19, 2006.

CARVAlHO, N. M.; NAKAGAWA, J. Sementes: ciência, tecnologia e produção. Jaboticabal: Funep, 2012. 590 p.

CATÃO, H. C. R. M.; COSTA, F. M.; VALADARES, S. V.; DOURADO, E. R.; BRANDÃO, D. S.; SALES, N. L. P. Qualidade física, fisiológica e sanitária de sementes de milho crioulo produzidas no norte de Minas Gerais. Ciência Rural, Santa Maria, v. 40, n. 10, p. 2060-2066, 2010.

CAUSSE, M.; ROCHER, J. P.; PELLESCHI, S.; BARRIÈRI, Y.; VIENNE, D.; PRIOUL, J. L. Sucrose phosphate synthase: an enzyme with heterotic activity correlated with maize growth. Crop Science, Madison, v. 35, p. 995-1001, 1995.

CHEN, S.; CHEN, H.; TIAN, J.; WANG, Y.; XING, L. Chemical modification, antioxidant and $\alpha$-amylase inhibitory activities of corn silk polysaccharides. Carbohydrate Polymers, Amsterdam, v. 98, n. 1, p.428-437, 2013.

COIMBRA, R. D. A.; MARTINS, C. C.; TOMAZ, C. A.; NAKAGAWA, J. Testes de vigor utilizados na avaliação da qualidade fisiológica de lotes de sementes de milho-doce (sh2). Ciência Rural, Santa Maria, v. 39, n. 1, p. 2402-2408, 2009.

COPELAND, L. O.; MC DONALD, M. B. Principles of seed science and technology. Annals of Botany, Oxford, v. 89, n. 6, p. 797-798, 2002.

DANTAS, B. F.; ARAGÃO, C. A.; ARAÚJO-JUNIOR, J. P.; RODRIGUES, J. D.; CAVARIANI, C.; NAKAGAWA, J. Padronização da metodologia do RT-PCR utilizado para identificação do mRNA da $\alpha$-amilase em sementes de milho. Revista Brasileira de Sementes, Londrina, v. 24, n. 2, p. 113-117, 2002.

FERREIRA, L. A.; OLIVEIRA, J. A.; VON PINHO, E. V. R.; QUEIROZ, D. L. de. Bioestimulante e fertilizante associados ao tratamento de sementes de milho. Revista Brasileira de Sementes, Londrina, v. 29, n. 2, p. 80-89, 2007.

FRANCO, O. L.; RIGDEN, D. J.; MELO, F. R.; GROSSI-DE-SÁ, M. F. Plant $\alpha$-amylase inhibitors and their interaction with insect $\alpha$-amylases. European Journal of Biochemistry, Berlin, v. 269, p. 397-412, 2002.

FRIES, D. D.; ALVES, J. D.; DELÚ FILHO, N.; MAGALHÃES, P. C.; GOULART, P. F. P.; MAGALHÃES, M. M. Crescimento de plântulas do milho "Saracura' e atividade de $\alpha$-amilase e invertases associados ao aumento da tolerância ao alagamento exercido pelo cálcio exógeno. Bragantia, Campinas, v. 66, n. 1, p. 1-9, 2007.

GOMES, M. S.; VON PINHO, E. V. R.; VON PINHO, R. G.; VIEIRA, M. G. G. C. Efeito da heterose na qualidade fisiológica de sementes de milho. Revista Brasileira de Sementes, Londrina, v. 22 , n. 1, p. 7-17, 2000.

HENNING, F. A.; MERTZ, L. M.; JACOB JUNIOR, E. A.; MACHADO, R. D.; FISS, G.; ZIMMER, P. D. Composição química e mobilização de reservas em sementes de soja de alto e baixo vigor. Bragantia, Campinas, v. 69, n. 3, p. 727-734, 2010.

HOECKER, N.; KELLER, B.; PIEPHO, H.P.; HOCHHOLDINGER, F. Manifestation of heterosis during early maize (Zea mays L.) root development. Theoretical and Applied Genetics, Berlin, v. 112, n. 3, p. 421-429, 2006.

HONG-BO, S.; ZONG-SUO, L.; MING-AN, S. LEA proteins in higher plants: structure, function, gene expression and regulation.
Colloids and surfaces B: Biointerfaces, Amsterdam, v. 45, p. 131135,2005

JOSÉ, S. C. B. R.; VON PINHO, E. V. R.; VON PINHO, R. G.; RAMALHO, M. A. P.; SILVA FILHO, J. L. Controle genético da tolerância à alta temperatura de secagem em sementes de milho. Revista Brasileira de Milho e Sorgo, Sete Lagoas, v. 3, n. 3, p. 414-428, 2004a.

JOSÉ, S. C. B. R.; VON PINHO, E. V. R.; VON PINHO, R. G.; SILVEIRA, C. M. da. Padrões eletroforéticos da enzima a-amilase em sementes de milho submetidas a alta temperatura de secagem. Revista Brasileira de Sementes, Londrina, v. 26, n. 1, p. 77-83, 2004b.

KIGEL, J.; GALILI, G. Seed development and germination. New York: Jaime Kigel, 1995. 872 p.

KIBINZA，S.; BAZIN, J.; BAILLY, C.; FARRANT, J. M.; CORBINEAU, F.; EL-MAAROUF-BOUTEAU, H. Catalase is a key enzyme in seed recovery from ageing during priming. Plant Science, Limerick, v. 181, n. 3, p.309-315, 2011.

LEYMARIE, J.; VITKAUSKAITÉ, G.; HOANG, H. H.; GENDREAU, E.; CHAZOULE, V.; MEIMOUN, P.; CORBINEAU, F.; EL-MAAROUF-BOUTEAU, H.; BAILLY, C. Role of reactive oxygen species in the regulation of Arabidopsis seed dormancy. Plant and Cell Physiology, Kyoto, v. 1, n. 53, p. 96-106, 2011.

LI, L.; BLANCO, M.; JAY-LIN, J. Physicochemical properties of endosperm and pericarp starches during maize development. Carbohydrate Polymers, Amsterdam, v. 67, n. 4, p. 630-639, 2007.

LOVEGROVE, A.; HOOLEY, R. Gibberellin and abscisic acid signalling in aleurone. Trends in Plant Science, London, v. 5, n. 3, p. 102-110, 2000.

MASON-GAMER, R. J. The \{beta -amylase genes of grasses and a phylogenetic analysis of the Triticeae (Poaceae). American Journal of Botany, Saint Louis, v. 92, n. 6, p. 1045-1058, 2005.

MEYER, R. C.; WITUCKA-WALL, H.; BECHER, M.; BLACHA, A.; BOUDICHEVSKAIA, A.; DORMANN, P.; FIEHN, O.; FRIEDEL, S.; KORFF, M. V.; LISEC, J.; MELZER, M.; REPSILBER, D.; SCHMIDT, R.; SCHOLZ, M.; SELBING, J.; WILLMITZER, L.; ALTMANN, T. Heterosis manifestation during early Arabidopsis seedling development is characterized by intermediate gene expression and enhanced metabolic activity in the hybrids. Plant Journal, Oxford, v. 71, p. 669-683, 2012.

MINO, M.; INOUE, M. Analysis of glucose metabolism in the heterotic viability in seeding growth of maize F1 hybrid. Japanese Journal of Crop Science, Tokyo, v. 63, n. 4, p. 682-688, 1994.

MUNIZ, F. R.; CARDOSO, M. G.; VON PINHO, E. V. R.; VILELA, M. Qualidade fisiológica de sementes de milho, feijão, soja e alface na presença de extrato de tiririca. Revista Brasileira de Sementes, Londrina, v. 29, n. 2, p. 195-204, 2007.

NAKAJIMA, M.; SHIMADA, A.; TAKASHI, Y.; KIM, Y. C.; PARK, S. H.; UEGUCHI-TANAKA, M.; SUZUKI, H.; KATOH, E.; IUCHI, S.; KOBAYASHI, M.; MAEDA, T.; MATSUOKA, M.; YAMAGUCHI, I. Identification and characterization of Arabidopsis gibberellin receptors. The Plant Journal: for Cell and Molecular Biology, Oxford , v. 46, n. 5, p. 880-889, 2006.

OLIVEIRA, G. E.; VON PINHO, E. V. R.; ANDRADE, T.; SOUZA, J. C.; CAIXETA, F.; FERREIRA, R. A. Relationship among 
physiological quality, heterosis, and amylase gene expression in maize seeds. Genetics and Molecular Research, Ribeirão Preto, v. 14, n. 3, p. 8623-8633, 2015.

OLIVEIRA, G. E.; VON PINHO, R. G.; ANDRADE, T.; VON PINHO, E. V. R.; SANTOS, C. D.; VEIGA, A. D. Physiological quality and amylase enzyme expression in maize seeds. Ciência e Agrotecnologia, Lavras, v. 37, n. 1, p. 40-48, 2013.

PALEG, L. G. Physiological effects of gibberellins. Annual Review of Plant Physiology and Plant Molecular Biology, Palo Alto, v. 16, n.1, p. 291-322, 1965.

PIMENTEL, M. A.; VASCONCELlOS, M. C.; PENHA, R. O.; GUERRA, E. P.; SILVA, A. L. L. Ação de diferentes enzimas na germinação de sementes de alface (Lactuca sativa L.) - Asteraceae. Journal of Biotechnology and Biodiversity, Gurupi, v. 3, n. 3, p. 1-4, 2012.

RAMOS, A.; CARNEIRO, G. A. Envelhecimento artificial de sementes do pinheiro do Paraná. Pesquisa Agropecuária Brasileira, Brasília, v. 26, n. 1, p. 19-24, 1991.

REIS, L. S.; PEREIRA, M. G.; SILVA, R. F.; MEIRELES, R. C. Efeito da heterose na qualidade de sementes de milho doce. Revista Brasileira de Sementes, Londrina, v. 33, n. 2, p. 310-315, 2011.

ROOD, S. B.; BUZZELL, R. I.; MAJOR, D. J.; PHARIS, R. P. Gibberellins and heterosis in maize: quantitative relationships. Crop Science, Madison, v. 30, n. 2, p. 281-286, 1990.

ROOD, S. B.; LARSEN, K. M. Gibberellins, amylase, and the onset of heterosis in maize seedlings. Journal of Experimental Botany, Oxford, v. 39, n. 2, p. 223-233, 1988.

ROSA, S. D. V. F.; VON PINHO, E. V. R.; VIEIRA, M. G. G. C.; SANTOS, C. D.; VEIGA, R. D. Qualidade fisiológica e atividade enzimática em sementes de milho submetidas a secagem artificial. Revista Brasileira de Sementes, Londrina, v. 21, n. 1, p. 177-184, 2000 .

SANTOS, I. J.; SANTOS, Y. L.; OLIVEIRA, M. G. A.; SILVA, P. H. A. Expressão da alfa e beta amilase durante a germinação de cevada. Revista Brasileira de Produtos Agroindustriais, Campina Grande, v. 12, n. 1, p. 67-73, 2010.
SOPANEM, T.; LAURIÈRE, C. Release and activity of bound, b-amylase in a germinating barley grain. Plant Physiology, Maryland, v. 89, p. 244-249, 1989.

SUBBARAO, K. V.; DATTA, R.; SHARMA, R. Amylases synthesis in scutellum and aleurone layer of maize seeds. Phytochemistry, Leiden, v. 49, n. 3, p. 657-666, 1998.

TIMÓTEO, T. S.; MARCOS-FILHO, J. Seed performance of different corn genotypes during storage. Journal of Seed Science, Londrina, v. 35, n. 2, p. 207-215, 2013.

VIEIRA, A. R.; OLIVEIRA, J. A.; GUIMARÃES, R. M.; VON PINHO, E. V. R.; PEREIRA, C. E.; CLEMENTE, A. C. S. Marcador isoenzimático de dormência em sementes de arroz. Revista Brasileira de Sementes, Londrina, v. 30, n. 1, p. 81-89, 2008.

VIEIRA, A. R.; VIEIRA, M. G. G. C.; FRAGA, A. C.; OLIVEIRA, J.A.; SANTOS, C. D. Action of gibberellic acid (GA3) on dormancy and activity of a-amylase in rice seeds. Revista Brasileira de Sementes, Londrina, v. 24, n. 2, p. 43-48, 2002.

WATTANAKULPAKIN, P.; PHOTCHANACHAI, S.; RATANAKHANOKCHAI, K.; LAY KYU, K.; RITTHICHAI, P.; MIYAGAWA, S. Hydropriming effects on carbohydrate metabolism, antioxidant enzyme activity and seed vigor of maize (Zea mays L.). African Journal of Biotechnology, Nairobi, v. 11, n. 15, p. 3537-3547, 2012.

WU, Y.; CAMPBELL, M.; YEN, Y.; WICKS, Z.; IBRAHIM, A. A. $\mathrm{H}$. Genetic analysis of high amylose content in maize (Zea mays L.) using a triploid endosperm model. Euphytica, Amsterdam, v. 166, n. 2, p. 155-164, 2009.

XIE, Z.; ZHANG, Z. L.; HANZLIK, S.; COOK, E.; SHEN, Q. J. Salicylic acid inhibits gibberellin-induced alpha-amylase expression and seed germination via a pathway involving an abscisic-acid-inducible WRKY gene. Plant Molecular Biology, Zurich, v. 64, n. 3, p. 293-303, 2007. 